\title{
STRATEGIC PLANNING OF INFORMATION SYSTEMS AND INFORMATION TECHNOLOGY: CASE STUDY XYZ LTD
}

\author{
Raden Makaryo Nugrahadi ${ }^{1}$, Febriliyan Samopa ${ }^{2}$ \\ ${ }^{I}$ Master of Technology Management, Sepuluh Nopember Institute of Technology, Surabaya, Indonesia \\ ${ }^{2}$ Information Systems, Sepuluh Nopember Institute of Technology, Surabaya, Indonesia
}

\begin{abstract}
$X Y Z$ Ltd. is a company engaged in the distribution of cigarettes in Indonesia. The company has implemented a strategic plan of IS / IT is still not standard and well run. The above problems led to plans SI / IT at XYZ Ltd. that is not able to achieve business goals and objectives of the company. This can cause a decline in business profits and competitiveness XYZ Ltd. compared to other companies. From the description above, company will do strategic planning of IS / IT at XYZ Ltd. This study covers the analysis of the internal and external conditions in terms of both business and technology, and a SWOT analysis of the company and future needs interpretation using Value chain, Critical Success Factor and Balanced Scoredcard. The result of this research is a blueprint of strategic plan IS / IT in XYZ Ltd. Which included recommendation for improvements in the network structure to prevent bottlenecks in IT infrastructure. While at the SI system is recommended for the development of advanced ERP which it affects the portofolio application to supports the achievement of the vision and mission of the company.
\end{abstract}

Keywords: IS/IT Strategic Planning. Value Chain Analysis, Ward \& Peppard Methods, Criticial Success Factor and Balanced Scorecard

\section{INTRODUCTION}

Problems in the implementation of IS/IT in an organization can be considered a paradox of productivity (Roach, 1994). Where in the application of IS/IT has been implemented well, but from the other side as well as security, human resources, transparency, and others are the opposite. Furthermore, in application of the IS/IT is an investment IS/IT still has not managed to provide the expected benefits to the organization (Ward and Peppard, 2003). Corporate leaders are often faced with the fact that the capital expenditure (capex) for IS/IT fruitless up to a certain value in accordance with the amount of investment that has been made. The company uses the IS/IT for financial management, operational marketing, customer service, coordination between branch offices, production planning, inventory control, distribution and others launched. But it is unclear whether the use of IS/IT suchalready significantly produce more output (Robert Solow McCarty, 2001)

$\mathrm{XYZ}$ Ltd. is a company with business areas that have branches cigarette distribution from Sabang to Merauke. Where the distribution of goods from production plants in the sanctuary until the consumer must be submitted properly and correctly. Where IT's role in it is quite significant, because with all the IT processes that initially the manual can be turned into terotomisasi well. Hopefully, by the plan of the IS/IT can align with the business plan of the company. So as to accelerate and assist in achieving the company's goal of being the number one cigarette distribution company in Indonesia.

The strategic plan before they perceived benefits. It is based on the analysis of the Quality Assurance team as follows:

First reason is IT investment does not directly support the company's business objectives. That in this case the IT department is still a cost center rather than a profit center. IT activity still focuses on the manufacture and purchase of tools such as hardware, software to ERP implementation. It is still not determined the business goals, targets to be achieved, the expected contribution, and corporate strategies which should be supported from the purchase of these tools. In the absence of targets to be achieved, the contribution of the IT organization is also difficult to measure.

Second, Control over the IT is reduced, it can be seen from the user is responsible for determining the actual IT goals. Demand for the system development IS/IT department of marketing tend to be only concerned with its own function. So that there is a system that helps a department but it will be difficult or not in line with the wishes of the other departments.

Third, Regarding the perception of the contribution of IS/IT is lacking. It can be evaluated from the entire project IS/IT only assessed based on financial context alone, so the project IS/IT will look expensive but not a lot to contribute tangible. 
Therefore, IT Quality Assurance team assess the benefits of investment in the field of IS/IT has not had a significant contribution in supporting the efficiency and effectiveness of the company's business activities. Thus the required implementation of the strategic plan better, which is expected to be realized.

\subsection{Relationship between Business Strategy, IS}

\section{Strategy and IT Strategy}

From Figure 1.1 it can be concluded that the company should treat IS/IT as part of the business like marketing, production or purchase, which must be carried out effectively and efficiently to business survival, but also can provide a sense of competitive and strategic for the company if managed intelligently.

This implies an approach to developing strategies for information systems and technology derived from and integrated with other components of the business strategy.

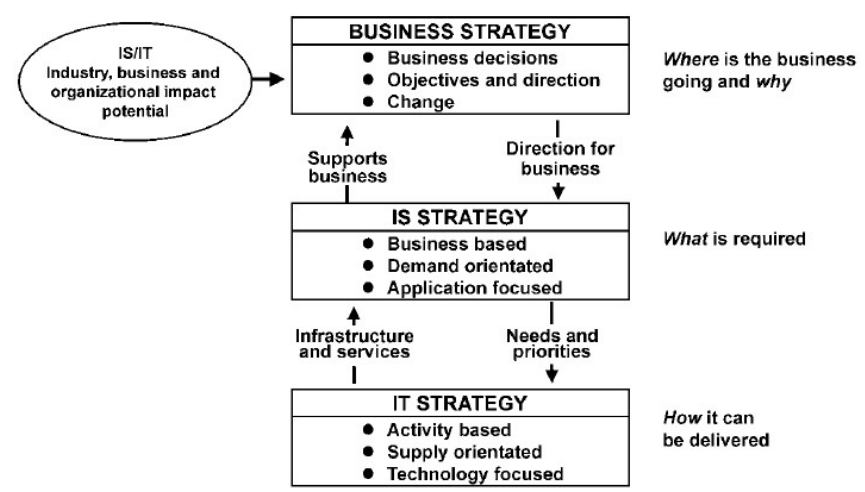

Fig 1. 1 Relationship between Business Strategy, IS Strategy and IT Strategy

If the company develops the marketing division as part of a business strategy, it should be analyzed first is the marketing position. After evaluating the marketing needs and the options available in relation to other needs. The diagram shows the same thing to be treated in the field of IS/IT. Identifying the potential impact first, and then evaluate the information and systems needed to provide a strategy and determine the best way to get the information system using existing technology. The model may be too simple to handle complex business quickly based on environmental changes. But it can be a good starting point to clarify the relationship between the problems encountered.

One of the methodologies used in the strategic planning of IS/IT is a methodology version of Ward and Peppard. Figure 1.2 shows a model of strategic planning / IT Ward and Peppard.

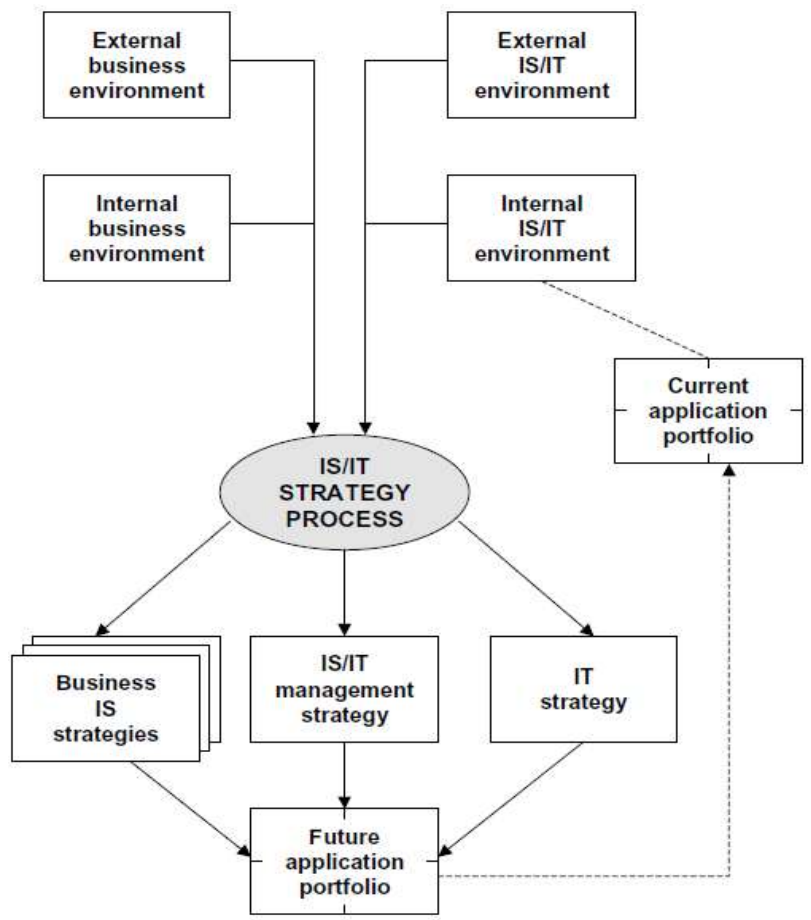

Fig 1. 2 Strategic Model IS/IT

\subsection{Strategic Planning Information Systems and Information Technology}

Planning a strategy of IS / IT is defined strategic thinking and planning for long-term management of effective and optimal impact of information in all its forms: Information Systems (IS) and Information Technology (IT) system combines manual and computer, computer and telecommunications technology. It also includes aspectsof management organization IS/IT. Quick but somewhat narrow definition offered by Lederer and Sethi is a "Process of deciding goal for computing the organization and identify potential computer applications that organizations should be implemented."

\subsection{IT Balanced Scorecard}

Balanced Scorecard Information Technology (IT BSC) introduced by Van Grembergen and Van Bruggen in 1997. IT BSC is a derivative of the Balanced Scorecard is exacerbated by Kaplan and Norton in 1992, but the concept is emphasized for use by division or IT department. IT BSC stressed that the IT organization is not only judged by financial achievement, but how much to contribute to the company's business. Therefore, IT BSC has a different perspective to the traditional BSC Kaplan and Norton. The difference as shown by the table below:

Table 1.1 The difference between IT BSC and BSC

\begin{tabular}{|l|l|}
\hline IT BSC & Traditional BSC \\
\hline Corporate Contribution & Financial \\
\hline Customer Contribution & Customer \\
\hline Operational Excellence & Internal \\
\hline Future Orientation & Learning and Growth \\
\hline
\end{tabular}




\section{METHODOLOGY}

In this chapter will discuss the research methods for the strategic planning of IS/IT with methods Ward and Peppard (2002). This paper, requires a relatively complete information data as a material that supports the truth and accuracy of the data.

\subsection{Preliminary Stage}

At this stage it will be explained about the problems faced by XYZ Ltd.company associated with information systems and information technology is the background of this research will be studied so worth doing as research objects. Then define research objectives to obtain the benefits that can be obtained.

\subsection{Collecting Data and Information Stage}

After preliminary stage, the next process is to obtain the information needed in order to achieve the research objectives. Interest expressed in hypothetical form a temporary answer to question research. The answer remains to be tested empirically, and for the purpose of data collection is required. The data collected is determined by the variables that exist in the hypothesis. Data was collected by a sample that had been predetermined. The sample consists of a set unit of analysis as a research target. Activities undertaken in this phase include the study of literature, study of institutional documents, interviews and observation.

\subsection{Understanding of Existing Condition Stage}

At this stage is to find out the latest conditions in the company in terms of business environment and the environment of IS/ IT companies. The external environment of business XYZ company is affected by factors beyond the control of the company, but it can influence the decisionmaking process and internal business processes of the company. The purpose of this analysis to determine any threats and opportunities that can affect the company.

Author use PEST analysis and Porter's five forces. For understanding the company's external environment by conducting analysis related to political, economic, social and technology that may affect the company's business operations could use PEST analysis. Then Porter's five force focust on environmental aspects of the industry will be lead on the competition aspects where the company is located. As a result, the factors that affect the conditions of competition, such as threats and strengths of the company, including the conditions of competition itself becomes necessary to be analyzed.

Furthermore, next step is author will discuss the internal analysis of the business in the XYZ Ltd.. Used to analyze the basic business requirements as needed. There are two methods for performing an analysis of the internal environment of business. The first isBusiness Strategy Analysis for conduct an analysis of the vision, mission and goals of the business strategy of XYZ company obtained by examining documents and interviewing company. The second method is value chain analysis, to identify activities that are involved in the business process and integration between the processes involved in XYZ Ltd. Internal environment anaylsis IS/IT will be next process. It will be discussed on the internal elements of the environment that need to be identified, analyzed and understood from XYZ Ltd..Regarding the analysis of external factors analysis of IS / IT are also discussed in this section. All analyzes performed in the previous process will be combined using SWOT analysis. Describes the strategic planning method used to evaluate the strengths, weaknesses, opportunities, and threats in a project or a business venture.

\subsection{Interpretation Future Needs Stage}

This stage describes how the conditions expected by XYZ Ltd. through a series of needs analysis in IS/IT services using value chain analysis, IT balanced scorecard and CSF analysis. The results of these three methodologies performed the analysis again using gap analysis to get the gap between the current state to the desired future needs.

\subsection{Strategy Formulation Stage}

At the stage of formulation of the strategy describes how the IT strategy formulation obtained from the analysis of the previous stage. The expected output consists of three kinds of IS business strategy, management strategy IS/IT and IT Strategy. IS business strategy explains how each part of dissemination and implementation of IS / IT in achieving the goals of the business. There are the information architecture of each unit. Until later be processed into a recommendation SI needs for further processing.

Whereas management strategies IS/IT explains the policies and strategies that will be used and applied to the company. Where view of the policy strategy of the IS/IT is now. Then create a better IS/IT strategy. At the end is determining the IT strategy, formulate policies and strategies to be blueprints infrastructure, human resources, organization and budget IS/IT which includes IT strategy planning mechanism.

\subsection{Determination Future Portfolio Application}

\section{Stage}

The result of the three formulations, namely business IS strategy, IS/IT management strategy, and IT strategy create a proposal for making of any application portfolio needed XYZ Ltd. in future

\section{CONCLUSION}

The process of formulating the strategic IS / IT for XYZ Ltd. has been made based on various analyzes conducted in the previous section. Starting with an analysis of the internal and external from the perspective of business and IS / IT. It can be deduced that the resulting recommendations can answer the needs of XYZ Ltd. by the increase stakeholder satisfaction, optimizing the company's image as well as add value to the company. Furthermore, the management can 
understand the circumstances faced by XYZ Ltd., so it can take the option solution should be used. Where one of them is using technology to meet the challenges of the future.

This is evidenced by recommendations for improvements in the network infrastructure that is more effective and efficient IT infrastructure. On the IS system, use of ERP applications that have modules needed by XYZ Ltd.as HR Management and Quality Management System. Which is expected to support the achievement of the vision and mission of the company.

\section{REFERENCES}

[1] Afuah, A. 2004. Business models: A strategic management approach. New York: Irwin/McGrawHill.

[2] Broadbent, M., Weill, P.. 1997. Management by Maxim: How business and Information Technology Management can create Information Technology Infrastructure.

[3] David, Fred, R. 2011. Strategic Management Manajemen Strategi Konsep, Edisi 12, Salemba Empat, Jakarta.

[4] David, F.R. 2013. Strategic Management: Concepts and Cases (14th ed.). Florence, South Carolina: Pearson.

[5] Earl, M. 1989. Management Strategic for Information Technology. Sidney: Prentice Hall.

[6] F Figge, T Hahn, S Schaltegger, M Wagner. 2002. The sustainability balanced scorecard-linking sustainability management to business strategy

[7] Freddy, Rangkuti. 2006. Teknik Mengukur dan Strategi Meningkatkan Kepuasan. Pelanggan. Jakarta : Penerbit PT Gramedia Pustaka Utama. Jogiyanto.

[8] Josua Tarigan, Onno W Purbo, Ridwan Sanjaya. 2010. Business-Driven Information Systems. Jakarta: Elex Media Komputindo.

[9] Kaplan, Robert S. dan David P. Norton. 2000, "Balanced Scorecard: Menerapkan strategi menjadi aksi”, Erlangga, Jakarta.

[10] Kaplan, Robert, S., \& Norton, David,P. 1996 : "The Balanced Scorecard: Translating Strategy Into Action”, Massachusetts,Harvard Business School Press.

[11] Management Study Guide. 2016. "Information Systems vs Information Technology", diakses pada 10 Oktober $2016 \quad$ melalui http://www.managementstudyguide.com

[12] McKay, Judith; Marshall, Peter; and Smith, Lisa. 2003, "Steps towards effective IT governance: strategic IS planning, evaluation and benefits management". PACIS Proceedings. Paper 65.

[13] Mohamed El Mekawy,Lazar Rusu,Nabeel Ahmed. 2009. Business and IT Alignment: An Evaluation of Strategic Alignment Models. : Springer Berlin Heidelberg.

[14] Michael E. Porter. 2008. The Five Competitive Forces That Shape Strategy. Harvard Business Review

[15] Porter, M. E. 2008. The Five Competitive Forces That Shape Strategy. Harvard Business Review, 1-17.

[16] Van Grembergen, W. and Van Bruggen, R."Measuring and improving corporate information technology through the balanced scorecard technique," Proceedings of the Fourth European Conference on the Evaluation of Information Technology, Delft, October 1997, pp. 163-171.

[17] Ward, John and Peppard, Joe. 2002. Strategic Planning for Information Systems Third Edition. Cranfield, Bedfordshire, UK 